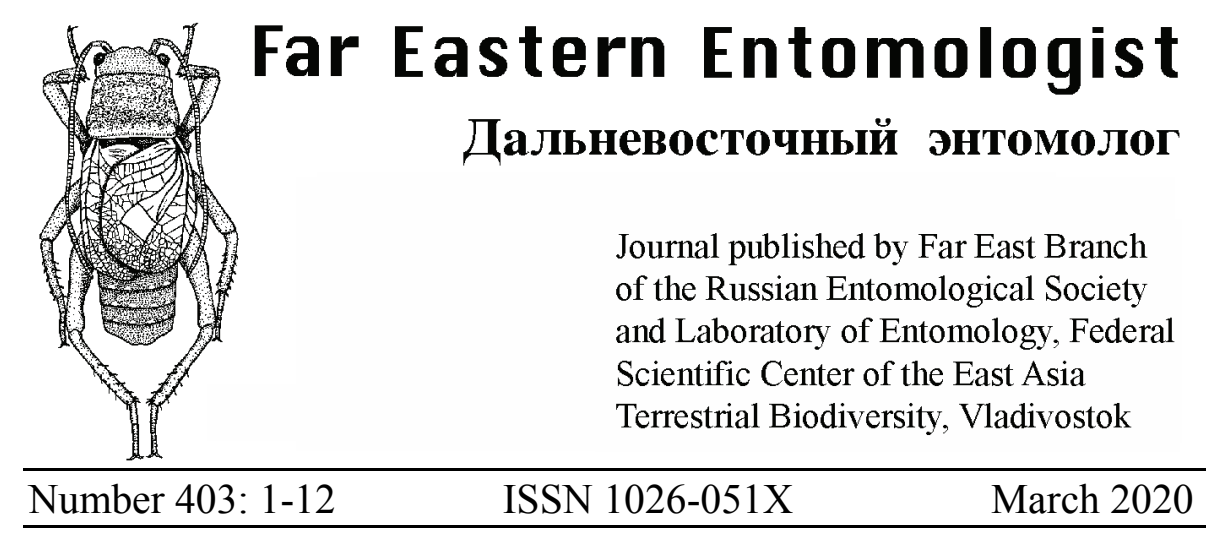

https://doi.org/10.25221/fee.403.1

http://zoobank.org/References/355AB608-E0A9-47FE-8751-041759EA32F3

\title{
A NEW GENUS OF DICTYOPHARIDAE (HOMOPTERA) FROM BITTERFELD AMBER BASED ON A NYMPH
}

\author{
A. F. Emeljanov ${ }^{1)}$, D. E. Shcherbakov ${ }^{2)}$ \\ 1 Zoological Institute, Russian Academy of Sciences, Universitetskaya Emb. 1, \\ St.-Petersburg, 199034, Russia.E-mail: alexandr.emeljanov@zin.ru \\ 2) A.A. Borissiak Paleontological Institute, Russian Academy of Sciences, \\ Moscow, Profsoyuznaya St. 123, Moscow, 117647,Russia.E-mail: dshh@narod.ru
}

Summary. Bathymyza longirostris gen. et sp. n. (Dictyopharinae: Orthopagini?) is described from an early instar nymph from Eocene Bitterfeld amber. The new genus is similar to Alicodoxa Emeljanov et Shcherbakov, 2011 based on nymphs from Eocene Rovno and Baltic ambers.

Key words: Fulgoroidea, planthoppers, Dictyopharinae, Orthopagini, fossil, Bitterfeld amber, Eocene.

А. Ф. Емельянов, Д. Е. Щербаков. Новый род Dictyopharidae (Homoptera) для нимфы из биттерфельдского янтаря // Дальневосточный энтомолог. 2020. N 403. C. 1-12.

Резюме. Bathymyza longirostris gen. et sp. n. (Dictyopharinae: Orthopagini?) описан по молодой нимфе из эоценового биттерфельдского янтаря. Новый род близок к Alicodoxa Emeljanov et Shcherbakov, 2011, установленному для нимф из эоценового ровенского и балтийского янтаря. 


\section{INTRODUCTION}

The planthopper family Dictyopharidae is poorly represented in the fossil record. Its earliest known member has been described from the Late Cretaceous (Santonian) amber of Taimyr and assigned to the extinct tribe Netutelini (Emeljanov, 1983). Szwedo (2008) described a monotypic genus from Baltic amber and placed it in a tribe of its own, Worskaitini, which he considered closely related to Netutelini. Several other Cenozoic genera have been attributed to the family, but most of them need re-examination to determine their systematic position in more detail (Szwedo et al., 2004). Based on dictyopharid nymphs from Rovno and Baltic ambers, the monotypic genus Alicodoxa Emeljanov et Shcherbakov, 2011 was established in the extant tribe Orthopagini (Emeljanov \& Shcherbakov, 2011). A similar nymph from Bitterfeld amber is described below as a new monotypic genus and tentatively assigned to the same tribe.

Bitterfeld amber from Saxony-Anhalt in Germany (Dunlop, 2010) and Rovno amber from NW Ukraine (Perkovsky et al., 2010) in their chemical composition and fossil assemblages are similar to Baltic amber and were often considered merely redeposited Baltic amber, transported by glaciers (Weitschat \& Wichard, 2010). The age estimates for these three ambers varied from Eocene to Oligocene (and even Miocene). Recent geochemical studies demonstrated that all three ambers are coeval, Eocene in age, and their source tree assemblages were similar, though Bitterfeld and Rovno ambers originated much farther south than Baltic amber (Wolfe et al., 2016; Mänd et al., 2018). The differences in floras and faunas of these ambers are chiefly due to their distinct source areas, separated in the Eocene by the North Sea and the future Paratethys: Baltic amber derived from the southern slopes of Fennoscandian High, whereas Bitterfeld and Rovno ambers from the northern slopes of Bohemian High and Volhynian High, respectively (Popov et al., 2004, Dunlop et al., 2018; Sokoloff et al., 2018). Present-day swampy forests in Florida were suggested as a possible analogue for the Bitterfeld amber forest (Dunlop, 2010).

The amber specimen described below was collected along with other amber inclusions from the opencast lignite mine Goitzsche, processed by VEB Ostseeschmuck Ribnitz-Damgarten and then transferred to and deposited in the Museum für Naturkunde - Leibniz-Institut für Evolutions- und Biodiversitätsforschung in Berlin (MB). Morphological terminology follows Emeljanov (1994, 1995). Photographs were taken using a Leica M165C stereomicroscope with a Leica DFC425 digital camera and processed with Helicon Focus 5.1.

\section{DESCRIPTIONS OF NEW TAXA}

Superfamily Fulgoroidea Latreille, 1807

Family Dictyopharidae Spinola, 1839

Subfamily Dictyopharinae Spinola, 1839

Tribe Orthopagini? Emeljanov, 1983 
Genus Bathymyza Emeljanov et Shcherbakov, gen. n.

http://zoobank.org/NomenclaturalActs/DB120ACE-89FB-4CC1-BBA8-C511FAB1CEF6

Type species: Bathymyza longirostris Emeljanov et Shcherbakov, sp. n.

DIAGNOSIS. Nymph (early instar). Similar to the extinct genus Alicodoxa, but distinct (character states of Alicodoxa in parentheses) in the longer rostrum reaching beyond the apex of the abdomen (beyond hind coxae), median carina of metope vestigial (distinct), fore legs not flattened (tibiae flattened), hind tibiae without lateral teeth (with five teeth), abdominal tergites VI-VIII without an additional small upper wax plate, and less numerous sensory pits.

COMPOSITION. Type species.

REMARKS. In the late instar holotype nymph of Alicodoxa rasnitsyni Emeljanov et Shcherbakov, 2011 a low median carina is developed on the metope and clypeus (not mentioned in the original description).

ETYMOLOGY. From Greek bathys (deep) and myzo (suck); gender feminine.

Bathymyza longirostris Emeljanov et Shcherbakov, sp. n.

http://zoobank.org/NomenclaturalActs/90c513ef-fb2a-4d91-9191-b39f2539d77a

Figs $1-11$

MATERIAL. Holotype, MB.I.1548, 1st (2nd?) instar nymph; Goitzsche near Bitterfeld; Bitterfeld (Saxonian) amber; Eocene.

DESCRIPTION. Young nymph of medium-sized planthopper. Dark brown (mostly covered with silvery gas film), moderately elongate, $3.2 \mathrm{~mm}$ long, $1.4 \mathrm{~mm}$ wide; head projecting forwards; dorsum finely transversely shagreened. Coryphe somewhat longer than wide, depressed towards median line, V-shaped in crosssection, with well-developed lateral carinae and median groove and vestigial transverse groove in distal half; its lateral and anterior margins forming nearly regular parabola, and posterior margin situated about eye midlength in dorsal aspect. Metope with vestigial median carina; intermediate carinae arched laterad; medial area broad, lancet-arched above, widest at 1/3 length from head apex, narrowed to clypeus; lateral areas parallel-sided, comparatively narrow, dorsally widened and faced laterad, with two rows of sensory pits; inner row of sensory pits reaching upper margin of clypeus, outer row incomplete ventrally, ending near lower eye margin, far from clypeus; both rows shortly interrupted slightly dorsal to lower eye margin (see Discussion). Boundaries of metope and postclypeus (epistomal suture) and of post- and anteclypeus arched dorsad, medially obsolete. Postclypeus with lateral carinae, without median carina, tapered apically, about as long as anteclypeus. Rostrum very long, reaching well beyond apex of abdomen, apical segment much shorter than subapical one. Pedicel thrice longer than scape, with at least 3 sensory plaque organs, third segment (base of flagellum) large, wider than $1 / 2$ of pedicel (see Discussion). 


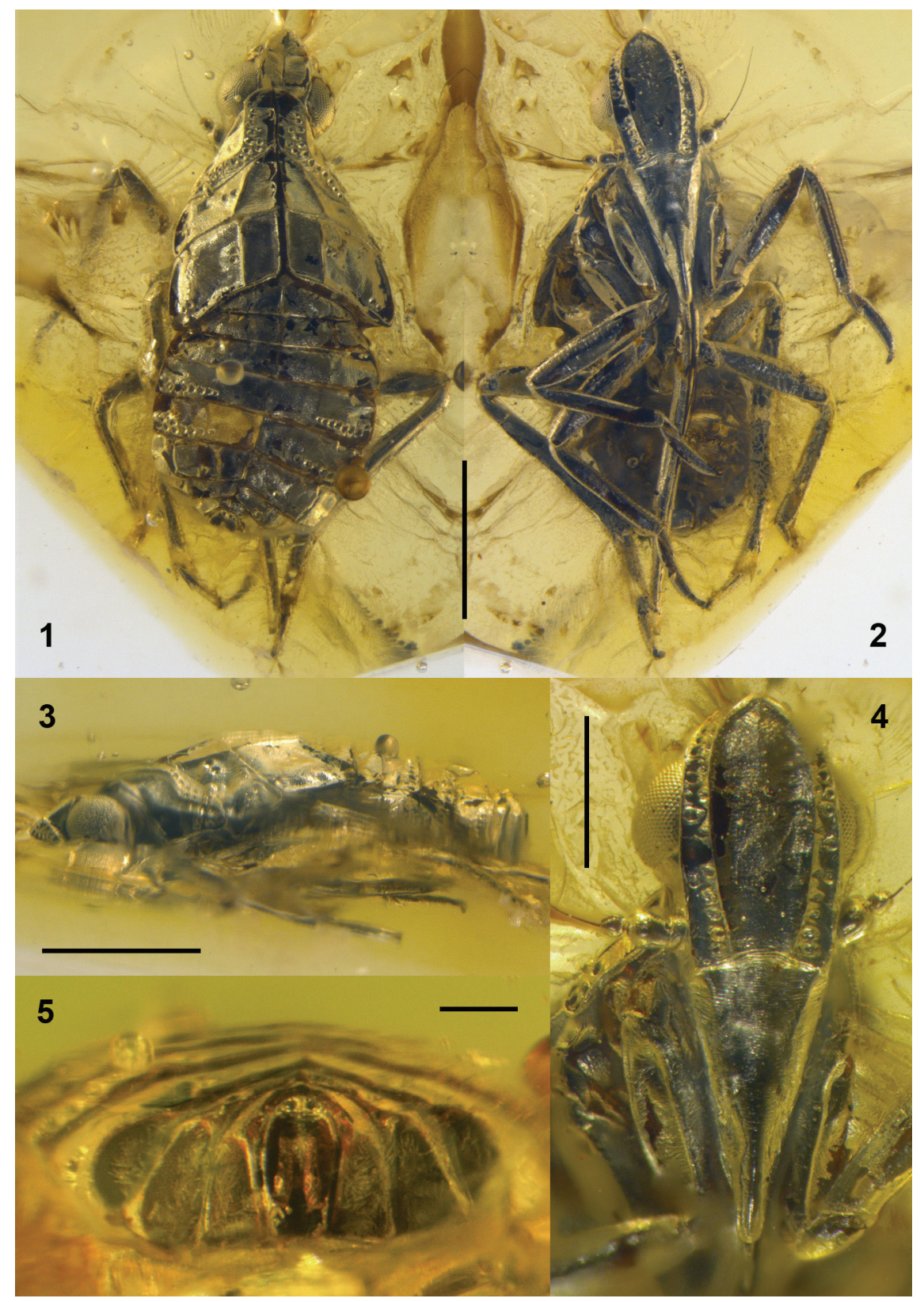

Figs 1-5. Bathymyza longirostris sp. n., holotype: 1 - habitus, dorsal view; 2 - habitus, ventral view; 3 - habitus, lateral view; 4 - head, ventral view; 5 - abdomen, caudal view. Scale bars, $1 \mathrm{~mm}(1-3), 0.5 \mathrm{~mm}$ (4) and $0.2 \mathrm{~mm}$ (5). 
Pronotal disc strongly projecting forwards (more than $1 / 2$ of its median length situated anterior to level of posterior eye margins), its anterior margin arcuately convex, anterolateral angles obtuse, lateral margins anteriorly parallel, then curved, posteriorly diverging backwards. Posterior margin of pronotum with deep, nearly right-angled emargination reaching almost $1 / 4$ of pronotal disc length. Pronotal disc slightly

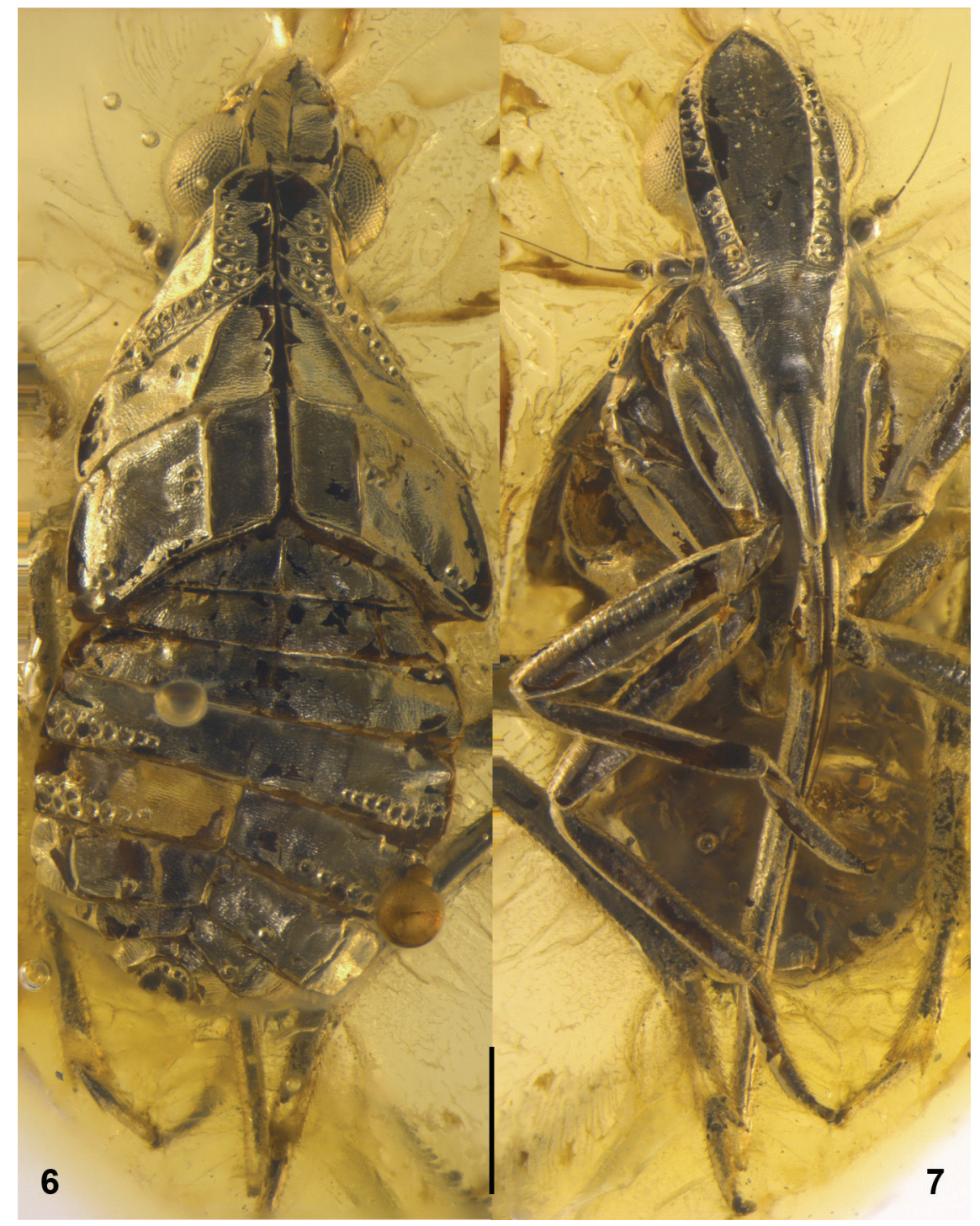

Figs 6-7. Bathymyza longirostris sp. n., holotype: 6 - body, dorsal view; 7 - body, ventral view. Scale bar, $0.5 \mathrm{~mm}$. 
wider than, and about as long along midline as, coryphe, bordered with distinct carinae along anterior and anterolateral margins; median carina distinct; posterolateral discal carinae absent, boundary between discal and paradiscal areas traceable only as flexure of surface plane (posterior ends of these flexures close to points where lateral carinae of mesonotal disc approach pronotal margin). Sensory pits of pronotal

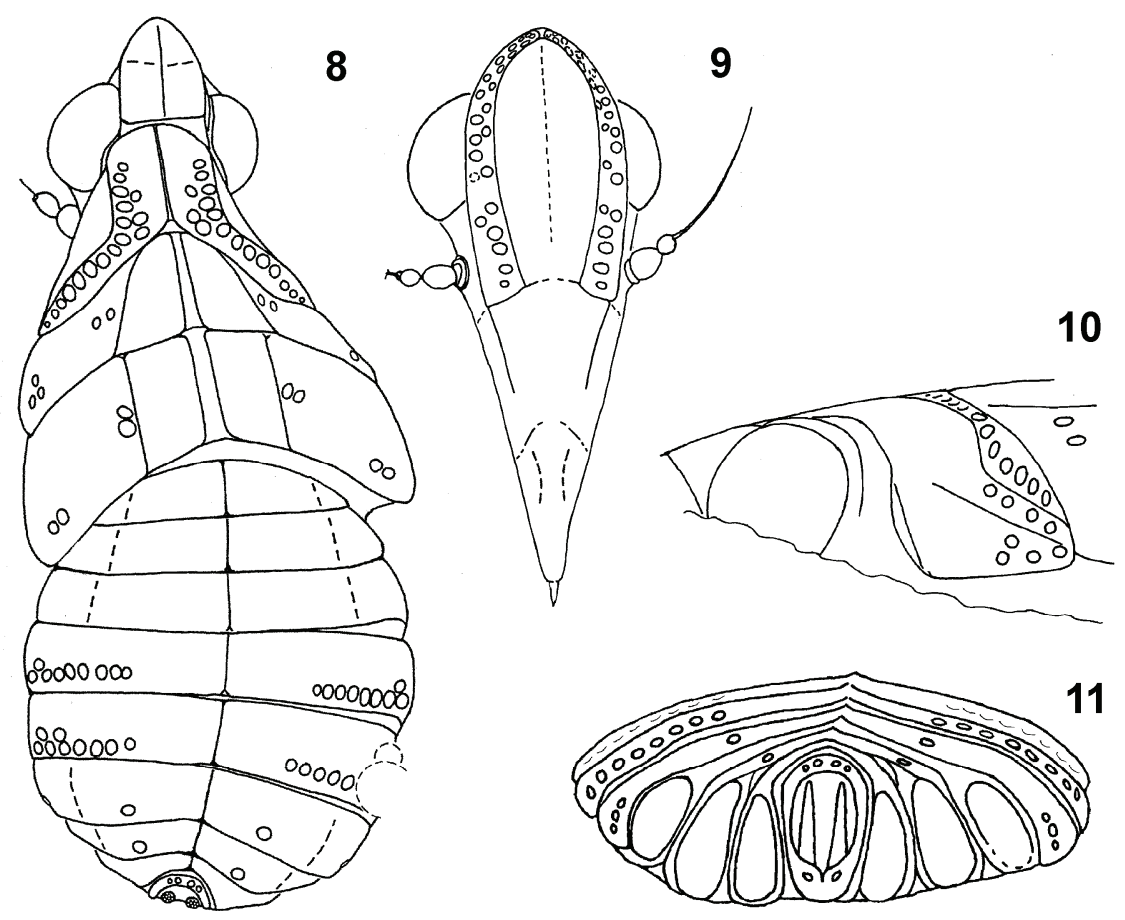

Figs 8-11. Bathymyza longirostris sp. n., holotype: 8 - body, dorsal view; 9 - head, ventral view; 10 - pronotum, lateral view; 11 - abdomen, caudal view.

disc and paradiscal areas forming one entity: disc with row of 6 larger pits along lateral margin and 3 smaller pits in second, more medial row; paradiscal area with 7 pits in marginal row. Humeral area with 4 pits in row; pectoral group of 4 pits near posterior margin of paranotal lobe. Lateral and collateral carinae distinct. Mesonotal disc arrow-shaped anteriorly, discal carinae converging there nearly at right angle, running parallel to posterior pronotal margin; median carina double; 2 pits in oblique row laterad of discal carinae. Paradiscal area of mesonotum near lateral margin posteriorly with 3 pits (in triangle). Wing pads not developed yet; lateral margin of mesonotum shorter than that of metanotum. Metanotal disc rectangular, about 1.2 times as wide as long, with all carinae distinct; median carina double; 2 pits in oblique or subtransverse row laterad of discal carinae (similar to that on mesonotum); paradiscal area near lateral margin subapically with 2 pits in oblique row. Fore legs 
not flattened, similar to, and slightly longer than, mid legs. Fore femora without subapical tooth on posteroventral carina. Fore and mid tibiae not widened, relatively slender. Hind tibiae without lateral spines, with 4 spaced apical teeth. Hind tarsus two-segmented, tarsomere I with 4 spaced apical teeth, tarsomere II much shorter than I, without lateral teeth; claws small.

Abdomen with well-developed middorsal carina, weak intermediate carinae (absent on tergites IV-V), and without sublateral carinae. Tergites I-III without pits. Tergites IV-V with long (complete) rows of 9-10 pits, 8th pit (from body midline) displaced anteriad (sometimes there are 2 such pits, 6th and 8th, forming rudimentary second row anteriorly - see Fig. 8). Tergite VI with 1 pit medially and 3 pits laterally, VII with 1 pit medially, VIII without pits. Laterotergite VIII not enlarged. Tergite IX with 2 medial pits dorsally and 1 pit ventrally (at each side). Wax plates situated in subtriangular posterolateral areas of tergites VI-VIII, separated from rest of tergite by carina and facing posteriad. Wax plates of uniform structure, large, crescent-shaped (VI) to subtriangular, with individual wax filaments discernible.

ETYMOLOGY. From Latin longus (long) and rostrum (bill, beak).

\section{DISCUSSION}

\section{Instar of the holotype nymph}

The character changes from instar to instar are similar and comparatively well studied in Dictyopharidae and Delphacidae (Lindberg, 1939; Emeljanov, 1980, 1994, 1995, 2001; Wilson \& McPherson, 1981a, b; Wilson \& Tsai, 1984, 1991; Wilson, 1985; Calvert \& Wilson, 1986; Tsai \& Wilson, 1986; Wilson \& Wheeler, 1986; Calvert et al., 1987a, b; Holder \& Wilson, 1992; Wilson et al., 1992; McPherson \& Wilson, 1995). Some characters of the B. longirostris sp. n. holotype are more or less instar-specific.

1. In Bathymyza gen. n., lateral areas of metope bear two rows of sensory pits, the complete inner row reaching the epistomal suture and the ventrally incomplete outer row, ending far from clypeus, as usual in Dictyopharidae. In late instars of some Orthopagini (Orthopagus Uhler, 1897; Tenguna Matsumura, 1910) the outer row of sensory pits is extended towards the clypeus, but these are secondary, smaller pits reaching slightly ventral to antennae (not quite accurately shown by Yang \& Yeh, 1994). It is noteworthy that in the B. longirostris sp. n. holotype nymph both these rows of sensory pits are interrupted dorsal to the lower eye margin. This feature appears in the first instar nymphs: in some higher Orgeriinae (Otottetix Oshanin, 1913; Repetekia Oshanin, 1913), and to a lesser degree in some Dictyopharinae (Nersia florens Stål, 1862, Nersiini; Emeljanov, 1994, figs 12, 17, 21).

2. The third antennal segment (base of flagellum) is wider than $1 / 2$ of the pedicel in the first instar nymphs of Delphacidae (Lindberg, 1939; Asche, 1985) and Dictyopharidae (Emeljanov, 1980, 1994). In the second instar it is slightly narrower than the pedicel. In later instars, the third segment gradually becomes smaller compared to the second, so that in adults it is almost equal in thickness to the flagellum. 
3. Sensory plaque organs of the pedicel usually appear in the second instar, except for e.g. Phylloscelis pallescens Germar, 1839 (Phylloscelini) having 3 plaques already in the first instar (McPherson \& Wilson, 1995).

4. Position of the wax plates is not reliable enough to determine instars. In younger instars of Dictyopharidae they usually lie in the plane of the upper surface of the abdomen, and in the later (IV-V) instars in the transverse subvertical plane (Emeljanov, 1980, 1994).

5. The number of apical teeth on hind tarsomere I and hind tibia is $4(2+2)$ in the first instar and $6(3+3)$ in the second (Emeljanov, 2001).

6. The number of sensory pit rows in discal-paradiscal area of the pronotum: one (second row absent) in the first instar; two (Dictyophara pannonica (Germar, 1830); Emeljanov, 1980) or one (Nersia florens; Wilson \& McPherson, 1981a) in the second instar; always two in the third instar.

7. Development of wing pads: the difference between I-III instars in the relative length of fore and hind wing pads is not clearly expressed.

8. Lateral spines of hind tibiae are absent in the first instar and as a rule appear already in the second instar, though they may be very small, as in Asiraca clavicornis (Fabricius, 1794) (Delphacidae; Asche, 1985).

In the Bathymyza longirostris sp. n. holotype nymph, characters 1, 2, 5, and possibly 8 point to the first instar, 3 to the second (or maybe first), 6 to the second, and 4 rather to some later instar. Despite such a discordance, we suppose that this is most probably the first instar nymph.

In the fifth instar nymphs of many genera of various Dictyopharinae tribes, including Alicodoxa, a small upper wax plate was discovered adjacent to the large one (Emeljanov \& Shcherbakov, 2011). The absence of these small wax plates in Bathymyza gen. n. may be due to its early instar. The early instars of extant Orthopagini are still unstudied.

According to our data, in planthoppers the body length of the fifth instar is nearly twice larger than that of the second (AFE, pers. obs.). Therefore, the adults of $B$. longirostris sp. $\mathbf{n}$. were medium-sized planthoppers, with the body length over $1 \mathrm{~cm}$. The adults of Alicodoxa rasnitsyni were smaller (body length of the fourth instar holotype nymph is $4.1 \mathrm{~mm}$ ).

\section{Systematic position}

The new genus is similar to Alicodoxa and likewise assigned to the subfamily Dictyopharinae based on the general habitus and presence of typical wax plates on the VI-VIII abdominal tergites (undeveloped in another subfamily, Orgeriinae), and to the tribe Orthopagini based on the arrow-shaped anterior convergence of the lateral carinae of the mesonotal disc, combined with one or few sensory pits being displaced forwards (or forwards and backwards) from rows on the abdominal tergites IV-V (see Yang \& Yeh, 1994; the latter character is found only in Orthopagini, the former also in Nersiini). The subapical tooth on the fore femur is characteristic of most Orthopagini but absent in several species of Centromeria Stål, 1870, Alicodoxa, and the new genus. The early instar nymphs of Nersiini differ from B. longirostris $\mathbf{s p .} \mathbf{n}$. by less numerous sensory pits, absence of the collateral carina of pronotum, and laterotergites VIII extended medially. 
However, two features make placement of the new genus in Orthopagini somewhat doubtful. An unusual character of Bathymyza gen. n. is the presence of sensory pits (2 pairs) on the dorsal side of tergite IX medially. Such pits are characteristic of Delphacidae, Cixiidae and Achilidae (Yang \& Yang, 1986; Yang, 1989; Yang \& Yeh, 1994) standing lower than Dictyopharidae in the phylogeny of Fulgoroidea. Achilidae likewise show 2 pairs of these pits, and some Fulgoridae as well [2 pairs according to the text in "Fulgoridae sp. 2"of Yang \& Yeh (1994), identified as Pyrops sp. by Emeljanov (2009)]. These pits are absent in all studied nymphs of Dictyopharidae.

The dorsal pits on the tergite IX and the abovementioned discordance in the instar-specific characters may indicate that Bathymyza gen. n. and Alicodoxa belong to an extinct primitive tribe of Dictyopharidae.

The only extinct tribe of Dictyopharidae recorded in the Cenozoic is Worskaitini known from a single specimen. The nymphs of Alicodoxa rasnitsyni and B. longirostris sp. n. differ from the adult of Worskaito stenexi Szwedo, 2008 by the wider, less elongate head (the head elongation in Dictyopharinae, if it occurs, proceeds gradually from instar to instar) and also by the flattened fore tibia (A. rasnitsyni) or longer rostrum (B. longirostris). However, this extinct tribe, like the existing ones, may include taxa with different head shapes, so it cannot be ruled out that both genera based on nymphs belong to Worskaitini.

\section{Biology}

The exceptionally long rostrum reaching beyond the apex of the abdomen in $\mathrm{Ba}$ thymyza gen. $\mathbf{n}$. is consistent with the assumption that these nymphs dwelt on the bark of amber-producing trees. In the Mesozoic such extremely long rostra were rather common among Auchenorrhyncha (e.g. Palaeontinidae, Tettigarctidae, Fulgoridiidae, Mimarachnidae, Dorytocidae), indicating that in the past feeding on trees with thick and rough bark was more widespread than today (Shcherbakov \& Popov, 2002; Shcherbakov, 2017; Emeljanov \& Shcherbakov, 2018). In the Cenozoic and recent fauna similar rostra are found only in a few planthoppers, e.g. in some Cixiidae (Mnemosyne Stål, 1866 and other Mnemosynini; Szwedo et al., 2006), some Dictyopharinae (Pippax Emeljanov, 2008), and some Orgeriinae (Ticrania chamberlini (Van Duzee, 1923)) - these latter do not live on typical trees, but are reported e.g. from tree-like Yucca brevifolia (Ticida Uhler, 1891 and Yucanda Ball et Hartzell, 1922 - Emeljanov, 1980: 39; Schneider, 2020). A similar trait occurred in aphids: very long rostra, sometimes much longer than the body, are found in many Cretaceous and Paleogene genera in different families, whereas today Stomaphis Walker, 1870 is the only genus with extremely long rostrum (Heie \& Wegierek, 2009) - twice the body length or more, enabling these aphids to probe through the bark crevices.

\section{ACKNOWLEDGEMENTS}

We are deeply grateful to Christian Neumann (Museum für Naturkunde, Berlin) for providing photographs of amber planthoppers and arranging the loan of the 
specimen, Vladimir Gnezdilov (Zoological Institute RAS, St.-Petersburg) for bringing the specimen to us, and Roman Rakitov (Paleontological Institute RAS, Moscow) for valuable comments. The study was supported by the Russian Foundation for Basic Research grants 16-04-01143 and 18-04-00322.

\section{REFERENCES}

Asche, M. 1985. Zur Phylogenie der Delphacidae Leach, 1815 (Homoptera Cicadina Fulgoromorpha). Marburger Entomologische Publikationen, 2(1): 1-910.

Calvert, P.D. \& Wilson, S.W. 1986. Life history and descriptions of the immature stages of the planthopper Stenocranus lautus (Homoptera: Delphacidae). Journal of the New York Entomological Society, 94(1): 118-125.

Calvert, P.D., Tsai, J.H. \& Wilson, S.W. 1987. Delphacodes nigrifacies (Homoptera: Delphacidae): Field biology, laboratory rearing and descriptions of immature stages. Florida Entomologist, 70(1): 29-134.

Calvert, P.D., Wilson, S.W. \& Tsai, J.H. 1987. Stobaera concinna (Homoptera: Delphacidae): Field biology, laboratory rearing and descriptions of immature stages. Journal of the New York Entomological Society, 95 (1): 91-98.

Dunlop, J.A. 2010. Bitterfeld amber. P. 57-68. In: Penney, D. (Ed.). Biodiversity of Fossils in Amber. Siri Scientific Press, Manchester. 304 p.

Dunlop, J.A., Kotthoff, U., Hammel, J.U., Ahrens, J. \& Harms, D. 2018. Arachnids in Bitterfeld amber: A unique fauna of fossils from the heart of Europe or simply old friends? Evolutionary Systematics, 2: 31-44. DOI: https://doi.org/10.3897/evolsyst.2.22581

Emeljanov, A.F. 1980. Phylogeny and evolution of subfamily Orgeriinae (Homoptera, Dictyopharidae). Lectures in memory of N.A. Kholodkovsky, 32: 3-96. [In Russian]

Emeljanov, A.F. 1983. Dictyopharidae from the Cretaceous deposits on the Taymyr Peninsula (Insecta, Homoptera). Paleontological Journal, 17(3): 77-82.

Emeljanov, A.F. 1994. Morphological peculiarities of larvae of the family Dictyopharidae (Homoptera). I. General characteristics and a key to genera of the Palearctic fauna. Entomological Review, 73(5): 59-78.

Emeljanov, A.F. 1995. Morphological peculiarities of larvae of the family Dictyopharidae (Homoptera). II. Developmental changes. Entomological Review, 74(8): 40-59.

Emeljanov, A.F. 2001. Larval characters and their ontogenetic development in Fulgoroidea (Homoptera, Cicadina). Zoosystematica Rossica, 9: 101-121.

Emeljanov, A.F. 2009. Evolutionary transformations of abdominal wax-plates in the larvae of the Fulgoroidea (Homoptera, Cicadina). Entomological Review, 89(9): 1035-1054.

Emeljanov, A.F. \& Shcherbakov, D.E. 2011. A new genus and species of Dictyopharidae (Homoptera) from Rovno and Baltic amber based on nymphs. ZooKeys, 130: 175-184. DOI: https://doi.org/10.3897/zookeys.130.1775

Emeljanov, A.F. \& Shcherbakov, D.E. 2018. The longest-nosed Mesozoic Fulgoroidea (Homoptera): A new family from mid-Cretaceous Burmese amber. Far Eastern Entomologist, 354: 1-14. DOI: https://doi.org/10.25221/fee.354.1

Heie, O.E. \& Wegierek, P. 2009. A classification of the Aphidomorpha (Hemiptera: Sternorrhyncha) under consideration of the fossil taxa. Redia, 92: 69-77.

Holder, M.W. \& Wilson, S.W. 1992. Life history and descriptions of the immature stages of the planthopper Prokelisia crocea (Van Duzee) (Homoptera: Delphacidae). Journal of the New York Entomological Society, 100(3): 491-497. 
Lindberg, H. 1939. Der Parasitismus der auf Chloriona-Arten (Homoptera Cicadina) lebenden Strepsiptere Elenchus chlorionae n. sp. sowie die Einwirkung derselben auf ihren Wirt. Acta Zoologica Fennica, 22: 1-179.

Mänd, K., Muehlenbachs, K., McKellar, R.C., Wolfe, A.P. \& Konhauser, K. 2018. Distinct origins for Rovno and Baltic ambers: Evidence from carbon and hydrogen stable isotopes. Palaeogeography, Palaeoclimatology, Palaeoecology, 505: 265-273. DOI: https://doi.org/10.1016/j.palaeo.2018.06.004

McPherson, J.R. \& Wilson, S.W. 1995. Life history and descriptions of immatures of the dictyopharid planthopper Phylloscelis pallescens (Homoptera: Fulgoroidea). Journal of the New York Entomological Society, 103(2): 170-179.

Perkovsky, E.E., Zosimovich, V.Y. \& Vlaskin, A.P. 2010. Rovno amber. P. 116-136. In: Penney, D. (Ed.). Biodiversity of Fossils in Amber. Siri Scientific Press, Manchester. 304 p.

Popov, S.V., Rögl, F., Rozanov, A.Y., Steininger, F.F., Shcherba, I.G. \& Kovac, M. (Eds) 2004. Lithological-paleogeographic maps of Paratethys. 10 maps Late Eocene to Pliocene. Courier Forschungsinstitut Senckenberg, 250: 1-74.

Schneider, K. 2018. Another Ticida individual. Bugguide. Available from: https://bugguide. net/node/view/1537748/bgimage

Shcherbakov, D.E. 2017. First record of the Cretaceous family Mimarachnidae (Homoptera: Fulgoroidea) in amber. Russian Entomological Journal, 26: 389-392.

Shcherbakov, D.E. \& Popov, Yu.A. 2002. Order Hemiptera Linné, 1758. The bugs, cicadas, plantlice, scale insects, etc. P. 143-157. In: Rasnitsyn, A.P. \& Quicke, D.L.J. (Eds). History of Insects. Dordrecht, Kluwer. xii +517 pp.

Sokoloff, D.D., Ignatov, M.S., Remizowa, M.V., Nuraliev, M.S., Blagoderov, V., Garbout, A. \& Perkovsky, E.E. 2018. Staminate flower of Prunus s. 1. (Rosaceae) from Eocene Rovno amber (Ukraine). Journal of Plant Research, 131(6): 925-943. DOI: https:// doi.org/10.1007/s10265-018-1057-2

Szwedo, J. 2008 A new tribe of Dictyopharidae planthoppers from Eocene Baltic amber (Hemiptera: Fulgoromorpha: Fulgoroidea), with a brief review of the fossil record of the family. Palaeodiversity, 1: 75-85.

Szwedo, J., Bourgoin, T. \& Lefebvre F. 2004. Fossil Planthoppers (Hemiptera: Fulgoromorpha) of the World. An Annotated Catalogue with Notes on Hemiptera Classification. Studio 1, Warsaw, 200 pp.

Szwedo, J., Bourgoin, T. \& Lefebvre, F. 2006. New Mnemosynini taxa (Hemiptera, Fulgoromorpha: Cixiidae) from the Palaeogene of France with notes on their early association with host plants. Zootaxa, 1122: 25-45.

Tsai, J.H. \& Wilson, S.W. 1986. Biology of Peregrinus maidis with descriptions of immature stages (Homoptera: Delphacidae). Annals of the Entomological Society of America, 79(3): 395-401.

Weitschat, W. \& Wichard, W. 2010. Baltic amber. P. 80-115. In: Penney, D. (Ed.). Biodiversity of Fossils in Amber. Siri Scientific Press, Manchester. 304 p.

Wilson, S.W. 1985. Description of the immature stages of Delphacodes bellicosa (Homoptera: Fulgoroidea: Delphacidae). Pan-Pacific Entomologist, 61(1): 72-78.

Wilson, S.W. \& McPherson, J.E. 1981a. Notes on the biology of Nersia florens (Homoptera: Fulgoroidea: Dictyopharidae) with descriptions of eggs, and first, second and fifth instars. Great Lakes Entomologist, 14(1): 45-48.

Wilson, S.W. \& McPherson, J.E. 1981b. Life history of Megamelus davisi with descriptions of immature stages. Annals of the Entomological Society of America, 74(4): 345-350. 
Wilson, S.W. \& Tsai, J.H. 1984. Descriptions of the immature stages and biology of Peregrinus maidis (Ashmead) (Homoptera: Delphacidae). Mitteilungen der Schweizerischen Entomologischen Gesellschaft, 57(4): 393-402.

Wilson, S.W. \& Tsai, J.H. 1991. Descriptions of nymphs of the delphacid planthopper Pissonotus delicatus (Homoptera: Fulgoroidea). Journal of the New York Entomological Society, 99(2): 242-247.

Wilson, S.W. \& Wheeler, A.G. 1986. Pentagramma longistylata (Homoptera: Delphacidae): Descriptions of immature stages. Journal of the New York Entomological Society, 94(1): 126-133.

Wilson, S.W., Tsai, J.H. \& Chen, C.C. 1992. Description of immatures of Eoeurysa flavocapitata Muir from Taiwan (Homoptera: Delphacidae). Pan-Pacific Entomologist, 68(2): 133-139.

Wolfe, A.P., McKellar, R.C., Tappert, R., Sodhi, R.N. \& Muehlenbachs, K. 2016. Bitterfeld amber is not Baltic amber: Three geochemical tests and further constraints on the botanical affinities of succinite. Review of Palaeobotany and Palynology, 225: 21-32. DOI: https://doi.org/10.1016/j.revpalbo.2015.11.002

Yang, C.T. 1989. Delphacidae of Taiwan (II). National Science Council Special Publication, 6: $1-334$.

Yang, J.T. \& Yang, C.T. 1986. Delphacidae of Taiwan (I). Asiracinae and the tribe Tropidocephalini (Homoptera: Fulgoroidea). Taiwan Museum Special Publication, Series 6: $1-79$.

Yang, C.T. \& Yeh, W.B. 1994. Nymphs of Fulgoroidea (Homoptera: Auchenorrhyncha) with descriptions of two new species and notes on adults of Dictyopharidae. Chinese Journal of Entomology Special Publication, 8: 1-189. 